\title{
Alternatif Yakıt Olarak Lignoselülozik Etanol Üretimi: İplikhane Pamuk Telefleri Üzerine Bir Çalışma
}

\author{
Aslı ABDULVAHITOĞLU*1 \\ ${ }^{1}$ Adana Alparslan Türkeş Bilim ve Teknoloji Üniversitesi, Mühendislik Fakültesi, Makine \\ Mühendisliği Bölümü, Adana
}

Geliş tarihi: 17.02.2019

Kabul tarihi: 28.06 .2019

$\ddot{\mathbf{O}} \mathbf{z}$

Enerji talebi, teknolojinin ve sanayinin gelişmesine paralel olarak her geçen gün artmakta, diğer taraftan en eski ve en çok kullanılan enerji kaynağ 1 olan fosil yakıtlar artan enerji ihtiyacı ile birlikte hızla tükenmektedir. Aynı zamanda hava kirliliği, sera gazı etkisi ve küresel ısınmadan dolayı yenilenebilir enerji kaynaklarının kullanımı ön plana çımaktadır. Lignoselülozik biyokütle bu yenilenebilir enerji kaynaklarından biridir. Etanol, lignoselülozik biyokütleden üretilebilir. Etanolün hammadde kaynağı olarak sadece yiyecek maddeleri ile çevresel öneme haiz olan ormanları kullanmayıp, tarımsal veya endüstriyel tarım atıklarından da elde edilebildiği için önem arz etmektedir. Bu nedenle bu çalışmada iplikhane pamuk telefleri kullanılarak sırası ile önhazırlık, piroliz, enzimatik hidroliz ve fermantasyon işlemleri yapılmıştır ve yaklaşık \%18,75 alkol dönüşüm oranı belirlenmiştir. Pamuk liflerinden $1000 \mathrm{~g}$ için ortalama 60,22 g etil alkol elde edilebileceği sonucuna ulaşılmıştır.

Anahtar Kelimeler: Etanol, Enzimatik hidroliz, Lignoselüloz

\section{Production of Lignocellulosic Ethanol as an Alternative Fuel: A Study on Cotton Yarn Wastes}

\begin{abstract}
Energy increases day by day in parallel with the development of technology and industry, on the other hand, the oldest and the most widely used energy source fossil fuels, are depleted rapidly by this demand. At the same time, the use of renewable energy sources is a priority for air pollution, greenhouse gas and global warming effect. Lignocellulosic biomass is one of these renewable energy sources. Ethanol can be produced from lignocellulosic biomass. As a source of raw materials, it is important not only to use forests that have ecological significance with foodstuffs but also for agriculture or industrial wastes. For this reason, in this study, the cotton yarn waste was used as raw material. Pyrolysis, enzymatic hydrolysis and fermentation were applied and ethyl alcohol was obtained and approximately 18,75\% alcohol conversion rate was determined. It was concluded that 60.22 grams of ethyl alcohol could be obtained for 1000 grams of cotton fibres.
\end{abstract}

Keywords: Ethanol, Enzymatic hydrolysis, Lignocellulose

*Sorumlu Yazar (Corresponding author): Aslı ABDULVAHITOĞLU, aabdulvahitoglu@atu.edu.tr 


\section{GíRiș}

Geleneksel olarak bilinen ve yaygın olarak kullanılan klasik enerji kaynakları hızla tükenmektedir. Aynı zamanda, bu kaynaklar çevre için büyük ve geri dönüşü olmayan tehlikelere de sebep olmaktadır. Klasik enerji kaynakları, artan ihtiyacı ve gelişen teknolojiyi beslemekte yetersiz kaldığından; gelişmiş ülkeler enerji çeşitliliğini artırarak, yayarak ve belli enerji kaynaklarına bağımlı kalmamaya çalışarak alternatif enerji arayışlarını sürdürmektedirler. Diğer yandan, yeni veya yenilenebilir enerji kaynaklarının çeşitliliği de artmaktadır. Bunların bir kısmı ekonomik olduğu için alternatif enerji kaynağı olarak değer kazanmaktadır. Tamamının ortak yönü ise çevreye olumsuz etkilerinin olmamasıdır. $\mathrm{Bu}$ nedenle, biyoyakıtların alternatif yakıt olarak kullanımları hızla yaygınlaşmaktadır.

Daha çok tarımsal ürünlerden ve atıklarından, değişik kimyasal yöntemler kullanılarak elde edilen biyoyakıtlar, genellikle benzin ve motorinle karıştırılarak birlikte kullanılmaktadır. Biyoyakıtlar;

- Fosil kökenli yakıtların neden olduğu çevresel tahribatı azaltması,

- Egzoz emisyonlarının sağlık açısından risklerini en aza indirmesi,

- Enerjide dışa bağımlılığı azaltması ve

- Tarımsal kalkınmaya katkı sağlaması nedeni ile gündeme gelmektedir.

Etanol otomobil yakıtı olarak ilk defa 1908 yılında Henry Ford tarafindan denenmiştir. Henry Ford'un denemesi başarılı olmasına rağmen benzin fiyatları etanole göre çok daha ucuz olduğundan, etanolün yakıt olarak kullanımı yaygınlaşmamıştır [1]. I. ve II. dünya savaşlarında yaşanan petrol kıtlığı, alkol tabanlı yakıtlara olan ilgiyi canlandırmıştır. 1970'lerdeki petrol krizi ise yenilenebilir alternatif yakıt kaynaklarına olan ihtiyacı tekrar gündeme getirmiştir [2].

Bunlardan biri olan etanol, eski çağlardan beri şekerin mayalanması ile elde edilmektedir. Etanol kimyasal formülü $\mathrm{C}_{2} \mathrm{H}_{5} \mathrm{OH}$ olan, temiz, renksiz, yanıcı ve oksijenatlı bir hidrokarbondur. Etanol elde etmek için önce, tarım ürünlerinde var olan nişasta şekere dönüştürülmekte ve müteakiben şekere mayalama işlemi yapılmaktadır. Etanolün çok değişik hammadde kaynakları bulunmakta olup; tahıl, melas, meyve, şarap, selüloz bunlardan bazılarıdır.

2017 yılında dünyada yaklaşık 481 milyon $\mathrm{m}^{3}$ etanol üretilmiştir. Brezilya ve ABD birlikte dünya etanol üretiminin \%84'ünü gerçekleştirirken, AB $\% 5$ 'ini üretmektedir [3]. Yakıt etanolu Brezilya'da şeker kamışından, ABD'de ise misırdan üretilmektedir. Türkiye'nin etanol üretim kapasitesi Çizelge 1'de gösterildiği gibi olup, toplam kapasite yıllık 150 bin $\mathrm{m}^{3}$ 'tür.

Çizelge 1. Türkiye'nin etanol üretimi [4]

\begin{tabular}{|l|c|c|c|}
\hline Firma Adı & $\begin{array}{c}\text { Üretim/yıl } \\
\mathrm{m}^{3}\end{array}$ & Şehir & Hammadde \\
\hline $\begin{array}{l}\text { Konya Şeker } \\
\text { Çumra Fabrikası }\end{array}$ & 84.000 & Konya & $\begin{array}{c}\text { Şeker } \\
\text { Pancarı }\end{array}$ \\
\hline $\begin{array}{l}\text { Tarımsal Kimya } \\
\text { Teknolojileri } \\
\text { (TARKİM) }\end{array}$ & 40.000 & Bursa & $\begin{array}{c}\text { Buğday, } \\
\text { Misır }\end{array}$ \\
\hline $\begin{array}{l}\text { Tezkim Tarımsal } \\
\text { Kimya (TEZKİM) }\end{array}$ & 26.000 & Adana & $\begin{array}{c}\text { Buğday, } \\
\text { Misır }\end{array}$ \\
\hline
\end{tabular}

Etanol yenilenebilir enerji olduğu için yakıt olarak kullanılması durumunda karbondioksit emisyonunun azalmasına da katkı sağlayacaktır. Etanol ve fosil yakıtlar yandıkları zaman her ikisi de havaya karbondioksit salmaktadır. Ancak etanolün yanması ile atmosfere salınan karbondioksit etanol üretiminde kullanılan hammadde kaynakları tarafından emildiğinden, ortaya çıkan $\mathrm{CO}_{2}$ nötr kabul edilmektedir. $\mathrm{Bu}$ nedenle etanolün alternatif motor yakıtı olarak kullanımı hızla yayılmaktadır.

Etanolün alternatif yakıt olarak kullanılması durumunda hızla nüfusu artan dünyada insanların gıda kaynaklarını etkilemeyecek hammadde kaynakları üzerinde durulmalıdır. $\mathrm{Bu}$ kapsamda yiyecekler, tahıllar, şekerler veya ormanlar kullanılmamalı, daha bol ve verimli olan selülozik hammaddeler, enzimler ve yeni teknolojiler kullanılarak selülozun parçalanması ve şekere dönüştürülmesi ile etanol elde edilmesi yoluna gidilmelidir. 
Dünya nüfusundaki artış ve yaşam standartlarındaki gelişme sonucunda tekstil tüketimi her geçen gün artmaktadır. Günümüzde tekstil endüstrisi ve tekstil yan sanayinde atıksız üretime tam olarak ulaşılamamıştır. $\mathrm{Bu}$ nedenle sıfır atık projesi kapsamında tekstil atıklarının asgariye indirilmesi ve yeniden kullanımı bu alanda çalışan tasarımcıların ana gündemi olmaktadır [5]. Tekstil atıkları deyince akla iplik ve kumaş üretimi esnasında ortaya çıkan atıklar ile hazır giyim üretimi esnasında ortaya çıkan kumaş artıkları gelmektedir [6].

Dünyada her yıl yaklaşık 1 milyon ton tekstil atığı ortaya çıkmaktadır. Bunların büyük bir kısmı iplik ve kumaş üretiminde ortaya çıkan tekstil teleflerinden oluşmaktadır. Bir ring işletmesinde karde iplik üretimi esnasında yaklaşık \%5,5-10,5, penye iplik üretiminde yaklaşık \%12, kumaş üretimi ve konfeksiyon aşamalarında ise yaklaşık $\% 23$ oranında telef ortaya çıkmaktadır [7]. Bu teleflerin bir kısmı yeniden işlenerek tekrar iplik üretiminde kullanılmaktayken büyük bir kısmı ise yakılarak yok edilmekte ya da düşük fiyatlarla dış ülkelere satılmaktadır. Ancak yapılan araştırmalar tekstil atıklarının birçok endüstriyel ürün için hammadde kaynağı olarak kullanılabileceğini göstermektedir [8,9].

$\mathrm{Bu}$ araştırmalarda pamuğun selüloz içeriği kuru ağırlığının \%85-95 oranında değiştiği görülmüş olup bu çok yüksek bir orandır ve biyoyakıta dönüştürülmesini kimyasal olarak mümkün kılmaktadır. Yapılan bir çalışmada, pamuğun yüksek oranda selüloz içeren nadir hammaddelerden biri olduğu tespit edilmiştir [10].

Chena ve arkadaşları (2007) [11], Tucker ve arkadaşları (2003) [12], Öhgren ve arkadaşları (2007) [13], Kaar ve Holtzapple (2000) [14] misir koçanından; Kristensen ve arkadaşları (2007) [15] buğday sapı, Cao ve arkadaşları (2012) tatlı sorgum [16], Oberoi ve arkadaşları (2010) pirinç sap1 [17] vb. gibi farklı lignosekükozik biyokütleler üzerinde çalışmalar yapmışlardır. Kimyasal yapısına bakıldığında içindeki \%80 selüloz içeriği ile pamuk diğer lignoselülozik yapılara göre etanol üretimi için daha iyi bir potansiyel olarak değerlendirilebilir [18]. Yapılmıs olan literatür taramasında kullanılması düşünülen iplikhane teleflerinden etanol üretimi hakkında bir çalışmaya rastlanmamıştır. Dolayısı ile yapılan bu araştırmanın ülkemizde sıfır atık projesi kapsamında öncü bir çalışma olacağı düşünülmektedir.

\section{ALTERNATIF YAKIT OLARAK ETANOL}

Etanol yakıt olarak, susuz etanol (\%100 etanol), sulu etanol (\%5 su- $\% 95$ etanol), susuz etanolbenzin karışımları (benzin içinde \%10-20 etanol) ve Etil Tersiyer Bütil Eter (ETBE) hammaddesi olmak üzere 4 farklı şekilde kullanılabilir [1]. Etanol ve benzinin yakıt değerleri Çizelge 2'de gösterildiği gibi olup daha çok karıştırılarak kullanılmaktadır. Etanol içten yanmalı motorlarda yüksek performans sağlamakta ve özellikle benzin ile karışım oranı arttığı zaman nispeten daha temiz yanmaktadır. Buharlaşma ve zehirli emisyonlarının oranı ise benzinden daha düşüktür [2].

$\mathrm{Bu}$ nedenle fosil yakıtların yoğun olarak kullanıldığı dünyada çevresel açıdan büyük sıkıntıların söz konusu olduğu günümüzde çözüm alternatiflerinden biri olarak biyoyakitlar gösterilmektedir. Biyoyakıtlar motorin veya benzin ile kıyaslandığında $\mathrm{CO}_{2}$ emisyonunu \%90 oranında azaltmaktadır [6].

Çizelge 2 Etanol'un yakıt olarak değerleri [19,20]

\begin{tabular}{|c|c|c|}
\hline Yakıt Tipi & Benzin & Etanol \\
\hline Yoğunluk $15^{\circ} \mathrm{C}(\mathrm{kg} / \mathrm{l})$ & $0,69-0,79$ & 0,789 \\
\hline $\begin{array}{l}\text { Kinematik viskozite } \\
\left(\mathrm{mPa} \mathrm{s} @ 20^{\circ} \mathrm{C}\right)\end{array}$ & $0,37-0,44$ & 1,19 \\
\hline Kaynama noktas $1\left({ }^{\circ} \mathrm{C}\right)$ & $27-225$ & 78,3 \\
\hline Parlama Noktas $1\left({ }^{\circ} \mathrm{C}\right)$ & -43 & 13 \\
\hline $\begin{array}{l}\text { Kendi kendine } \\
\text { tutusma sicakl } \breve{g ̆ g}_{1}\left({ }^{\circ} \mathrm{C}\right)\end{array}$ & 257 & 423 \\
\hline $\begin{array}{l}\text { Oktan Sayıs1 } \\
\text { (araştırma) }\end{array}$ & $88-100$ & 108,6 \\
\hline Oktan Say1s1 (motor) & $80-90$ & 89,7 \\
\hline
\end{tabular}

Etanol çeşitli ülkelerde \%5-\%25 oranlarında karışım olarak kullanılmaktadır. Çizelge 3'de yer alan bazı ülkelerde belli oranlarda etanol kullanılması zorunludur [41]. Ülkemizde ise resmi gazetede yayınlanan 27 Eylül 2011 tarihli ve 
28067 sayılı Tebliğ'e göre piyasaya akaryakıt olarak arz edilen benzin türlerinin, yerli tarım ürünlerinden üretilmiş etanol içeriğinin 2013 yılı itibariyle en az \%2, 2014 y1l itibariyle en az \%3 olması zorunludur [21].

Çizelge 3. Etanol kullanımı zorunlu olan bazı ülkeler ve oranları [22]

\begin{tabular}{|l|c|c|c|}
\hline Ülke & Oran & Ülke & Oran \\
\hline Arjantin & E5 & Pakistan & E10 \\
\hline Avustralya & E10 & Avusturya & E10 \\
\hline Brezilya & E20-E25 & Danimarka & E5 \\
\hline Paraguay & E18-E24 & Fransa & E5-E10 \\
\hline Kolombiya & E10 & Almanya & E5-E10 \\
\hline Hindistan & E5 & İlanda & E4 \\
\hline Yeni Zelanda & E10 & Kanada & E5 \\
\hline
\end{tabular}

Etanol üretimi için kullanılan hammaddeler genel olarak 3 sınıfa ayrılabilir. Bunlar;

- Sukroz içeren ham maddeler (şeker kamışı, şeker pancarı vb.),

- Nişasta içeren hammaddeler (mısır, buğday, pirinç) ve

- Lignoselülozik ham maddeler (Misır sapı ve buğday çöpü gibi tarımsal atıklar, odun ve enerji bitkileri)'dir [23].

Etanol üretimi için hangi hammadde kullanılırsa kullanılsın temel olarak Etanol fermantasyonunda hammadde olarak basit (monomerik) şekere ve ekmekçi mayasına (Saccharomyces cerevisiae) ihtiyaç duyulur. Geleneksel maya fermantasyonunda $1 \mathrm{~kg}$ herhangi bir altı karbonlu şekerden (glikoz, manoz veya sakaroz) $0,51 \mathrm{~kg}$ etanol üretilebilmektedir [24].

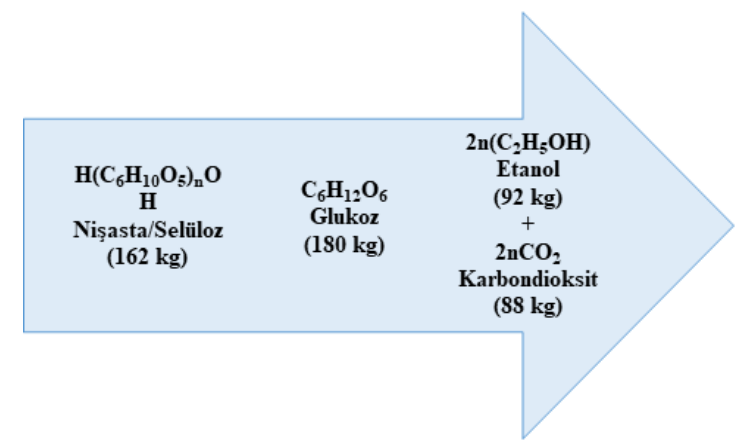

Şekil 1. Nişasta ve selüloz hidrolizini takiben glikozun ekmekçi mayası kullanılarak etanole dönüştürülmesi [24]
Şekerler doğrudan etanole dönüşebilirken daha karmaşık yapıdaki karbonhidratlar (nişasta ve selüloz) maya (fermantasyon enzimlerini üreten mikroorganizmalar) fermantasyon işlemini yapmadan önce basit şekerler haline parçalanmalıdır [25]. Daha elverişli ve düşük maliyetli kaynaklar elde etmek için ise, nişasta içermeyen, yiyecek ile ilgisi olmayan (yani besin zincirinde yer almayan) ağaçlar, otlar ve tarımsal atık vb. hammadde kaynakları üzerine odaklanılmalıdır. Daha bol ve verimli olan selülozik hammaddeler, enzimler ve yeni teknolojiler kullanılarak selülozun parçalanması ve selülozun şekere dönüştürülmesi yolu ile etanol elde edilmesi yoluna gidilmelidir.

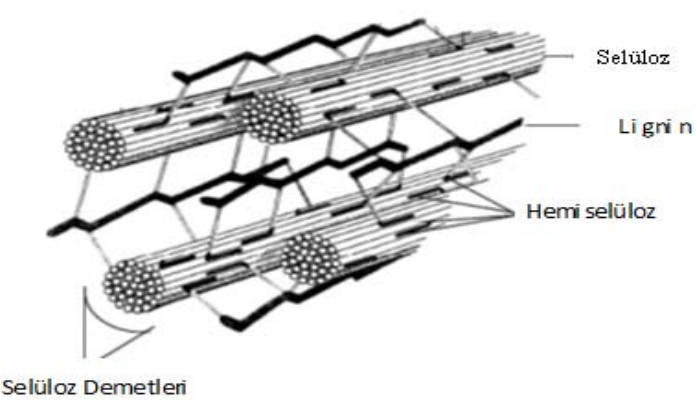

Şekil 2. Bitkisel hücre duvarı [24]

Lignoselülozik bitkilerin içerisinde ise selüloz, hemiselüloz ve lignin bulunur. Lignin bitkilerin dik durmasını sağlayan bir polimerdir. Hemiselüloz ve lignin bileşimi, selüloz çevresinde koruyucu bir zırh oluşturur ki bu zırh selüloz hidrolizi öncesinde verimli bir işlem yapılabilmesi için uzaklaştırılmalıdır. Lignin aynı zamanda temiz kömür (kükürtsüz) olarak bilinir [26].

Lignoselülozik biyokütle içinde yer alan selüloz ve hemiselülozun altı ve beş karbonlu şekerlere dönüştürülmesi etanol üretmek için gereklidir. Ancak bu dönüştürme işlemi nişastanın dönüştürülmesinden daha zordur. $\mathrm{Bu}$ sebeple lignoselülozik hammaddeden etanol üretmek için birkaç işlem yapılması gerekir. Bunlar;

- Ön-muamele (karbonhidratların monomerik şekerlere hidrolizinin daha hızlı ve daha fazla yapılması için),

- Hidroliz (karbonhidrat polimerleri monomerik şekerlere dönüştürülür),

- Fermantasyon ve ürünlerin saflaştırılmasıdır [23]. 
Selüloz biyokütle içerisinde genel karbon formunda bulunur. Aynı zamanda bir glikoz polimeridir. Yüksek dereceli hidrojen bağlarından dolayı kimyasal saldırılara karşı dirençli durumdadır. Biyokütlede bulunan 4 tip şeker polimer formu hemiselülozdur. Beş karbonlu şekerler (genellikle (D-galactose, D-glikoz ve D-mannose) ve üroyik asit ihtiva eder. Hemiselüloz sert kabuklu ağaçlardan hidrolize edildiği zaman Ksiloz (5 karbonlu), yumuşak ağaçlardan ise daha fazla altı karbonlu şeker elde edilir [26]. Yapısal malzeme, bilinen adiyla lignoselüloz lignin-selüloz matrisi içinde selüloz liflerinin çapraz bağlandığı bir kompozittir. Depolimerizasyon temel bitki bileşenleri için zordur çünkü lignoselüloz hem kimyasal hem de biyolojik saldırılara karşı dirençlidir.
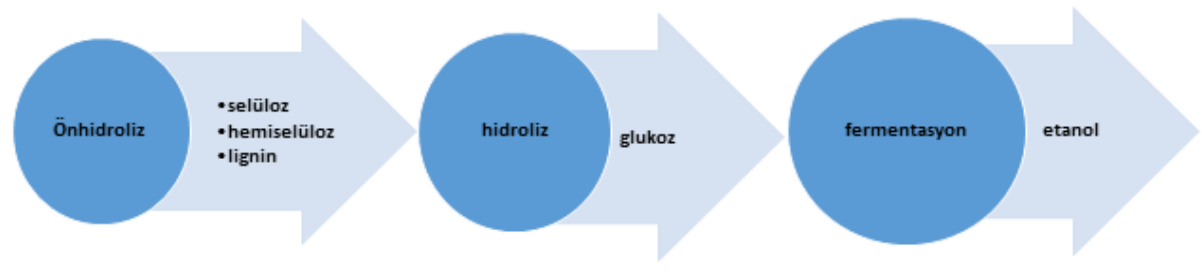

Şekil 3. Lignoselülozik etil alkol üretmek için uygulanan basamaklar

Ön işlem en pahalı adımlardan birisidir. Lignoselülozdan şekere dönüşümde, toplam işlem maliyetinin yaklaşık \%33'ünü oluşturur. Ön işlemde lignoselülozik malzemenin yüzey alanının artırılması önemli bir hedeftir. $\mathrm{Bu}$ işlem polisakkaritleri hidrolize işlemine (Şekil 4) daha yatkın yapar [27]. Ön işlem 4 ana başlıkta toplanabilir. Bunlar, Fiziksel, Kimyasal Önişlem, Fizikokimyasal Önişlem ve Biyolojik önişlem olarak sıralanabilir (Şekil 5).

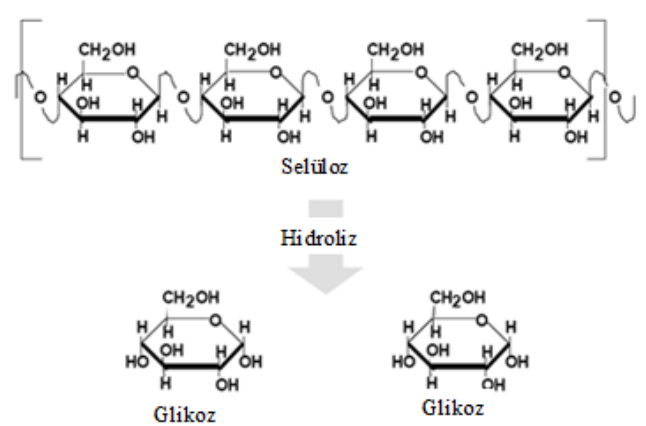

Şekil 4. Selüloz bağlarının kopartılarak glukoz şekerine dönüştürülmesi [24]

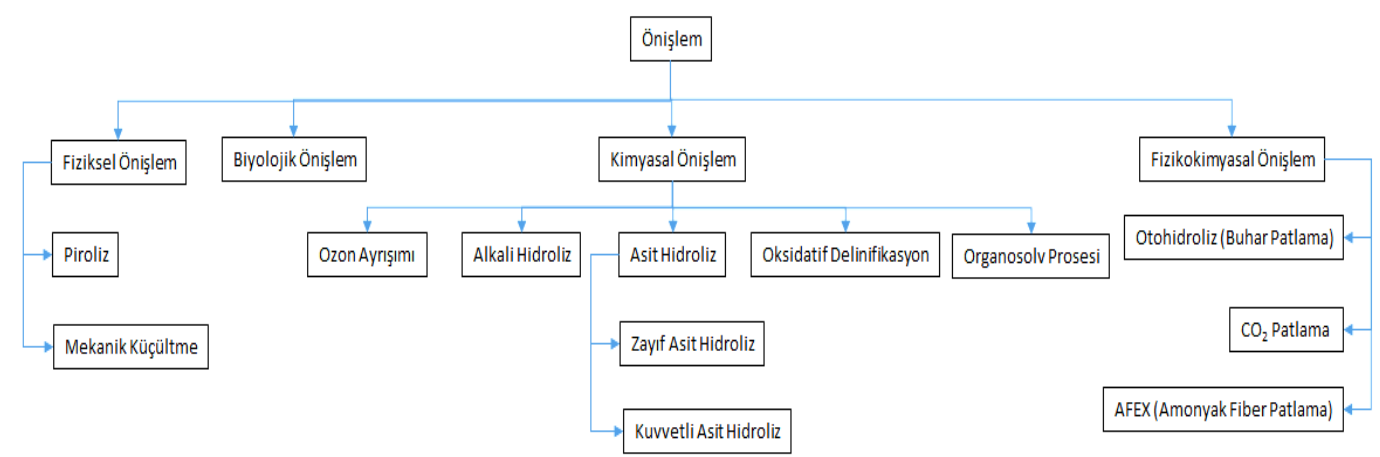

Şekil 5. Lignoselülozik hammaddeye uygulanabilen önişlemler 
Hidroliz ise önişlemden sonra yapılan ve selüloz ile hemiselülozu fermente edilebilen şekerlere dönüştürme işlemidir. İki tip hidroliz metodu bulunmaktadır: asit hidroliz (Konsantre asit hidroliz ve Zayıf asit hidroliz) ve enzimatik hidroliz. Enzimatik hidroliz işleminde enzimler vasıtası ile selüloz parçalanır ve şekere dönüştürülür. Enzimatik hidrolizin avantajı düşük sıcaklıkta ve minimum inhibitör oluşumu ile gerçekleşmesidir. Dezavantajı ise uzun süre gerektirmesi ve enzimlerin pahalı oluşu olarak gösterilebilir [28].

\section{MATERYAL ve METOT}

$\mathrm{Bu}$ çalışmada kullanılmak üzere Adıyaman ilindeki bir iplik firmasından penye pnömofil telefleri temin edilmiştir. Penye telefi, Ring ipliği üretim tesislerinde, harman hallaç kısmından geçen pamuk tarak ünitesine ulaşır ve cer ile vatka ünitelerinden de geçtikten sonra penyeye ulaşır. Penye bölümünde kısa lifler penyeleme işlemi sayesinde ayrılarak başka bir alanda biriktirilir ve "penye telefi" olarak adlandırılır.

Ham pamuğa göre oldukça temiz olan bu telefler, tekrar iplik yapımında kullanılabileceği hidrofil pamuk, para kağıdı, vb. maddenin yapımında kullanılabilmektedir. Penye telefi üzerinde toz, çepel, vb. yabancı madde miktarı çok düşük olduğu için hammaddeye ayrıca bir temizleme işlemi uygulanmamıştır.

\section{1. Ön İşlem ve Katı Ayrımı}

Pamuk lifinin kimyasal yapısı yetiştirme koșullarına bağlı olarak kısmen değișiklikler göstermekle birlikte ham pamuğun kimyasal bileşiminde \%88-96 oranında selüloz, \%0,5-0,6 oranında yağ ve vakslar, \%4-6 oranında hemiselüloz ve pektin, $\% 1,5-5$ oranında protein ve \%1-1,2 anorganik maddeler bulunmaktadır. Pamuklu materyale uygulanacak bazik işlemler ile selüloz yüzdesi \%99'a kadar ulaşmaktadır [29].

Çalışma kapsamında öncelikle biyokütle içerisinde bulunan lignin ve diğer yabancı maddeleri uzaklaştırmak için bazik işlemler ile ön hazırlık yapılmıştır. Bu işlem ile malzemenin yüzey alanı artırılması, içindeki selülozun ortaya çıkarılması amaçlanmıştır. Bu çalışmada pamuk teleflerinin ön hazırlık işleminde kullanılmış olan bazik işlem reçetesi ve çalışma diyagramı Çizelge 4'de gösterilmiştir.

Çizelge 4. Ön hazırlık reçetesi ve çalışma diyagramı

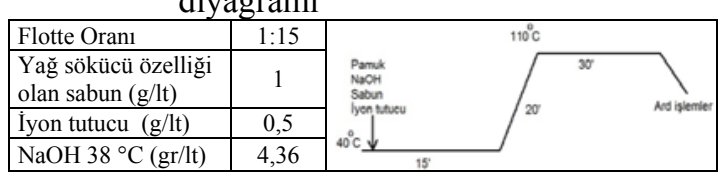

Ön hazırlık işleminin ardından pamuk lifleri iki kez $40{ }^{\circ} \mathrm{C}$ 'de $5 \mathrm{dk}$ boyunca durulama işlemine tabi tutulmuş ve $\mathrm{NaOH}$ artıklarının uzaklaştırılması için \%0,5'lik asetik asit çözeltisi ile muamele edilmiştir. Nötralizasyon işlemi sonrasında $40{ }^{\circ} \mathrm{C}$ 'de $5 \mathrm{dk}$ boyunca durulama işlemine tabi tutulmuş olan pamuk lifleri etüvde $60{ }^{\circ} \mathrm{C}$ 'de kurutularak ve 48 saat süreyle standart atmosfer şartlarında $\left(20 \pm 2 \quad{ }^{\circ} \mathrm{C} \quad\right.$ ve $\% 65$ nispi nem $)$ kondüsyonlanmıştır. $\mathrm{Bu}$ çalışmada ön hazırlık işleminden önce ve sonra yapılan ölçümler pamuk teleflerinin ön hazırlık işlemi esnasında \%5,36 ağırlık kaybına uğradığını göstermektedir.

\subsection{Piroliz, Enzimatik Hidroliz ve Fermentasyon Aşamaları}

Müteakiben araştırmalarda kullanılacak kondüsyonlanmış pamuk lifleri aşağıda belirtilen metotlar ile sırasıyla işleme tabi tutulmuştur.

Kondüsyonlanmış pamuk lifi örneklerinin pirolizi için "PARR (ABD)" yüksek basınç reaktörü (Şekil 6) kullanılmıştır. Örneklerin enzimatik hidrolizi ve fermantasyonu için "Thermo (ABD)" çalkalamalı inkübatör kullanılmıştır. Örneklerin şeker ve alkol analizi Yüksek Basınçlı Sıvı Kromatografisinde (HPLC) (Shimadzu LC-2030 C model ve RID 20A refraktif indeks dedektörlü) (Japonya) yapılmış ve kolon olarak "Bio-Rad HPX-87H (300 x 7,8 mm)” kullanılmıştır. Ayrıca bu çalışmada kullanılan kimyasallar Sigma (Sigma Chemical Company, MO, ABD) ve Merck (Merck KGaA, Darmstadt, Almanya) firmalarından temin edilmiştir. Cellic ${ }^{\circledR}$ CTec2 enzimi Novenzyme 
(Danimarka)'dan temin edilmiștir. Calıșmada kullanılan maya $S$. cerevisiae (FERMIVIN LS2, Oenobrands SAS, Fransa) instant mayadir.

\subsubsection{Piroliz}

Piroliz işlemi Parr (ABD) yüksek basınç reaktöründe gerçekleştirilmiştir. (Şekil 6). Ayrıca uygulamada "glassliner" kullanılarak yüksek sicaklık ve asit konsantrasyonun neden olduğu korozyonu [30] ve buna bağlı olarak oluşabilecek fermantasyon inhibitörlerini en aza indirmek amaçlanmıştır.

Sülfürik asit ile proliz için 5 gr kondüsyonlanmış pamuk lifi örneği $200 \mathrm{ml}$ sülfürik asit $(\% 0,5(\mathrm{~h} / \mathrm{h}))$ çözeltisi ile karıştırılarak $120{ }^{\circ} \mathrm{C}$ 'de 90 dk yükssek basınç reaktöründe tutulmuştur.

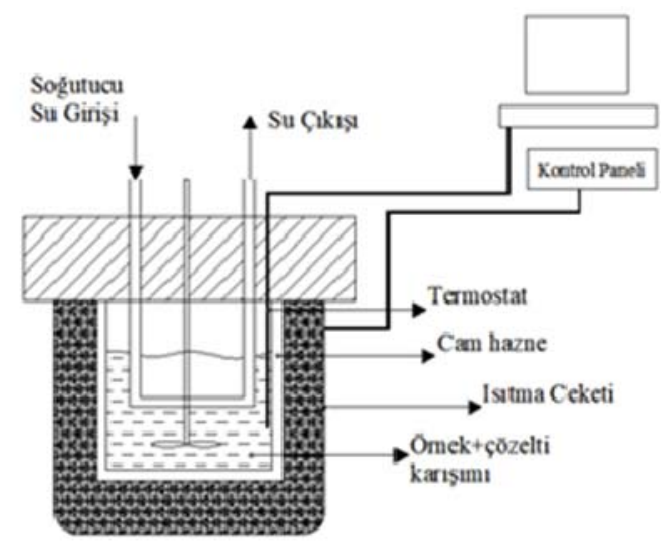

Şekil 6. Piroliz işlemlerinin gerçekleştirildiği reaktörün şekilsel gösterimi

\subsubsection{Enzimatik Hidroliz}

Piroliz işleminin ardından Enzimatik hidroliz işlemi için 100 ml'lik örnekler hazırlanmış, $10 \mathrm{M} \mathrm{NaOH}$ ile pH 5,0'a ayarlanmıştır. Mikrobiyal gelişimi önlemek amacı ile 0,5 g/L kloramfenikol ilave edilmiştir. Ardından 0,06 ml enzim/g Cellic CTec2 ilave edilerek çalkalamalı inkübatörde $50{ }^{\circ} \mathrm{C}$ 'de 200 devir/dakika karıștırma hızında hidroliz gerçekleştirilmiştir. 3 gün boyunca hidroliz işlemi devam etmiştir. 0,45 $\mu$ m'lik filtreden geçirildikten sonra HPLC'de analiz edilmiștir [31].

\subsubsection{Fermentasyon}

Etil alkol fermantasyonu için kullanılacak 0,2 g/L S. Cerevisiae (FERMIVIN LS2, Oenobrands SAS, Fransa) aktif kuru maya $20 \mathrm{~g} / \mathrm{L}$ glikoz, 8,5 g/L maya ekstrakt1, $1,32 \mathrm{~g} / \mathrm{L} \mathrm{NH}_{4} \mathrm{Cl}, 0.11 \mathrm{~g} / \mathrm{L} \mathrm{MgSO}_{4}$, ve $0,06 \mathrm{~g} / \mathrm{L} \quad \mathrm{CaCl}_{2}$ içeren $\mathrm{pH}$ 's 1 5,5 olarak ayarlanan siv1 besi yerinde $30{ }^{\circ} \mathrm{C}$ 'de 24 saat çoğaltılmıştır. Daha sonra maya süspansiyonu içeren besi yeri, alkol fermantasyonu yapılacak hidrolizat miktarının \%10 hacminde alınıp 4000 rpm'de $4{ }^{\circ} C^{\prime}$ de 10 dakika santrifüj edilmiştir. Santrifüj sonrasında maya, fermantasyonunun gerçekleştirileceği hidrolizat ile süspansiye edilerek alkol fermantasyonunun gerçekleştirileceği ortama eklenmiştir [32]. 3 gün fermenterde kalan örnekler HPLC'de analiz edilmiş ve alkol verimi, Eşitlik 1 kullanılarak hesaplanmıştır.

$\%$ Etanol Verimi $=\frac{\text { Oluşan Etanol Miktarı }}{\text { Fermente Edilen Şeker Miktarı }} \times 100$

HPLC ile şeker ve etil alkol tayini amaciyla enzimatik hidroliz ile fermantasyon işlemi sonunda alınan örnekler 5000 devir/dak'da 10 dakika santrifüj edildi. Santrifüj sonunda elde edilen süpernatant analizde kullanılmıştır. Bunun için örnekler 0,45 $\mu \mathrm{m}$ 'lik filtreden (Milipore MillexHV, Hidrofilik PVDF filtre) geçirilip HPLC'ye enjekte edilmiştir [33,34].

\section{HPLC koșulları:}

Enjekte edilen miktar: $20 \mu \mathrm{l}$

Taşıyıcı faz: $5 \mathrm{mM}$ 'lık sülfürik asit

Akış hızı: 0,5 ml/dak

\section{BULGULAR}

İplikhane pamuk teleflerine önişlem uygulanmış, akabinde kondüsyonlanmıştır. Kondüsyonlanmış pamuk lifi örnekler önce piroliz işlemine ardından sırası ile enzimatik hidroliz ve fermentasyon işlemi için inkübatöre alınmıştır. Ardından numuneler santrifüj işlemine tabii tutulmuştur. $\mathrm{Bu}$ aşamadan sonra örneklerin şeker ve alkol analizi yapılmıştır. Örneklerdeki şekerlerin konsantrasyonlarının belirlenmesinde diş standart yöntemi kullanılmıştır. $\mathrm{Bu}$ amaçla, bileşiklerin 
standartlarından (sükroz, glikoz, früktoz, gliserol, metanol, etanol) 6 farklı konsantrasyonda kalibrasyon çözeltileri hazırlanıp HPLC'de analiz edilmiştir. Numune 1 den elde edilen sonuca göre enzimatik hidroliz sonrası örnek içinde $0,367 \mathrm{~g}$ Sükroz, 5,583 g Glukoz ve 0,054 g arabinoz elde edilmiştir. İkinci numuneden ise $0,387 \mathrm{~g}$ Sükroz, 9,716 g Glukoz ve 0,053 g arabinoz elde edilmiştir (Çizelge 5).

Çizelge 5. Enzimatik hidroliz sonrası HPLC sonuçları

\begin{tabular}{|l|c|l|c|}
\hline \multicolumn{2}{|c|}{ 1. Numune (100 ml) } & \multicolumn{2}{c|}{ 2. Numune (100 ml) } \\
\hline Sükroz (g) & 0,367 & Sükroz $(\mathrm{g})$ & 0,387 \\
\hline Glukoz $(\mathrm{g})$ & 5,583 & Glukoz $(\mathrm{g})$ & 9,716 \\
\hline Früktoz $(\mathrm{g})$ & 0 & Früktoz $(\mathrm{g})$ & 0 \\
\hline Arabinoz $(\mathrm{g})$ & 0,054 & Arabinoz $(\mathrm{g})$ & 0,053 \\
\hline Gliserol $(\mathrm{g})$ & 0 & Gliserol $(\mathrm{g})$ & 0 \\
\hline Metanol $(\mathrm{g})$ & 0 & Metanol $(\mathrm{g})$ & 0 \\
\hline Etanol $(\mathrm{g})$ & 0 & Etanol $(\mathrm{g})$ & 0 \\
\hline
\end{tabular}

Çizelge 6. Fermentasyon sonrası HPLC sonuçları

\begin{tabular}{|l|c|l|c|}
\hline \multicolumn{2}{|c|}{ 1. Numune (100 ml) } & \multicolumn{2}{c|}{ 2. Numune (100 ml) } \\
\hline Sükroz $(\mathrm{g})$ & 0,366 & Sükroz $(\mathrm{g})$ & 0,386 \\
\hline Glukoz $(\mathrm{g})$ & 0,421 & Glukoz $(\mathrm{g})$ & 0,459 \\
\hline Früktoz $(\mathrm{g})$ & 0,285 & Früktoz $(\mathrm{g})$ & 0,296 \\
\hline Arabinoz $(\mathrm{g})$ & 0,065 & Arabinoz $(\mathrm{g})$ & 0,112 \\
\hline Gliserol $(\mathrm{g})$ & 0,195 & Gliserol $(\mathrm{g})$ & 0,12 \\
\hline Metanol $(\mathrm{g})$ & 0,41 & Metanol $(\mathrm{g})$ & 0,257 \\
\hline Etanol $(\mathrm{g})$ & 1,415 & Etanol $(\mathrm{g})$ & 1,596 \\
\hline
\end{tabular}

Fermentasyon sonrası numuneler HPLC cihazında analiz edilmiş ve sonuçlar Çizelge 6'da belirtilmiştir. Fermentasyon sonucunda birinci numuneden 1,415 g/100 ml, ikinci numuneden $1,596 \mathrm{~g} / 100 \mathrm{ml}$ etanol elde edilmiş olup ve ortalama $1000 \mathrm{~g}$ iplikhane pamuk telefinden $60,22 \mathrm{~g}$ etanol elde edilebileceği sonucuna varılmıştır. 1 no'lu denklem kullanılarak ortalama alkol verimi 15,79\% olarak hesaplanmıștır. Burada enzimatik hidroliz sonrası elde edilen sükroz, glukoz mayalanmış ve etil alkole dönüşmüştür. Arabinoz ise mayalanmamıştır. Fermentasyon işlemi sonucunda gliserol, metanol ve etanol meydana çıkmıştır.

\section{TARTISSMA VE SONUÇ}

$\mathrm{Bu}$ çalışmada iplikhane telefleri içerisindeki selülozdan etanol elde edilmeye çalışılmıştır. Telefler içerisindeki kristal yapı; selüloz, hemiselüloz ve ligninden oluşmaktadır. Öncelikle telefler içerisinde bulunan lignin ve diğer yabancı maddeleri uzaklaştırmak için ön hazırlık işlemi yapılmıştır. Bu işlem için yağ sökücü özelliği olan sabun, iyon tutucu, $\mathrm{NaOH}$ kullanılmıştır. Akabinde enzimatik hidroliz uygulamak için $200 \mathrm{ml}$ \%1,0’lik sülfürik asit çözeltisi ve $5 \mathrm{~g}$ kondüsyonlanmış pamuk lifleri ile karıştırılarak $120{ }^{\circ} \mathrm{C}$ 'de $90 \mathrm{dk}$ süre ile piroliz edilmiş. Reaktörde piroliz işlemi tamamlandiktan sonra pH's1 $10 \mathrm{M} \mathrm{NaOH}$ ile 5,0'a ayarlanıp mikrobiyal gelişimi önlemek amacı ile 0,5 g/L kloramfenikol ilave edilmiştir. Daha sonra novozymes Cellic CTec2 kullanılarak, çalkalamalı inkübatörde $50{ }^{\circ} \mathrm{C}^{\prime}$ de 200 rpm karıștırma hızında hidroliz gerçekleştirilmiştir. HPLC'de oluşan şeker miktarı ölçülmüştür. Akabinde 3 gün boyunca fermentasyonun gerçekleşeceği inkübatöre yerleştirilmiştir. HPLC ile şeker (sükroz, glikoz, früktoz) ve etil alkol tayini amaciyla piroliz sonucu, enzimatik hidroliz ve fermantasyon boyunca alınan örnekler 5000 rpm'de 10 dakika santrifüj edilerek ve santrifüj sonunda elde edilen süpernatant analizde kullanılmıştır. Bu çalışmanın sonucunda;

- HPLC yapılan ölçümler neticesinde iplikhane pamuk teleflerinden alkol eldesinin mümkün olduğu tespit edilmiş,

- Kullanılan kondüsyonlanmış pamuk liflerinden $1000 \mathrm{~g}$ için ortalama 60,22 g etil alkol elde edilebileceği sonucuna ulaşılmış,

- Yaklaşık \%18,75 alkol dönüşüm oranı belirlenmiş,

- $\mathrm{Bu}$ çalışmanın devamında Çukurova bölgesinde bulunan tekstil firmalarından sağlanacak olan işlem görmüş (boyanmış) tekstil teleflerinden etil alkol üretilebilirliğinin araştırılması planlanmıştır. $\mathrm{Bu}$ aşamadan 
sonra elde edilen etil alkolün susuzlaștırılarak saflaştırılması hedeflenmiştir.

Sonuç olarak iplikhane pamuk telefi kullanılarak etanol üretiminin hem sosyal hem de ekonomik yararları olacaktır. Bunlar:

- İthal petrole olan bağımlılığın azaltılması,

- İplikhane pamuk telefleri için alternatif pazarların oluşturulması,

- Karbon salınımının azaltılması ve

- Fosil yakitların yenilenebilir yakitlarla değişiminin sağlanmasıdır

\section{TEŞEKKÜR}

$\mathrm{Bu}$ proje, Adana Bilim ve Teknoloji Üniversitesi'nin Bilimsel Araştırma Projeleri Koordinasyon Birimi tarafindan 17103004 no'lu Bilimsel Araştırma Projesi olarak desteklenmiştir.

\section{KAYNAKLAR}

1. https://www.ag.ndsu.edu/energy/biofuels/energ y-briefs/history-of-ethanol-production-andpolicy 14.2.2018.

2. DiPardo, J., 2002. Outlook for Biomass Ethanol Production and Demand, https://www.agmrc.org/media/cms/biomass_E6 EE9065FD69D.pdf 14.02.2018.

3. https://ethanolrfa.org/resources/industry/statisti cs/\#1549569130196-da23898a-53d8 14.2.2018

4. http://depo.btu.edu.tr/dosyalar/sanayi/Dosyalar/ MURAT_ERTAS.pdf 14.2.2018.

5. Doğan, Z. Z., 2012. Tekstil Sektöründe Atık Ekolojisi Uygulamaları 1. Uluslararası Moda ve Tekstil Tasarımı Sempozyumu, 8-10 Ekim Antalya, 2012.

6. Eser, B., Çelik, P., Çay, A., Akgümüş, D., 2016. Tekstil ve Konfeksiyon Sektöründe Sürdürülebilirlik ve Geri Dönüşüm Olanakları, Tekstil ve Mühendis, 23(101), 43-60.

7. Celep, G., Doğan, G., Yüksekkaya, M.E., Tercan, M., 2016. Geri Dönüşümlü Lifler İçeren Süprem Kumaşların Isıl Konfor Özelliklerinin İncelenmesi, Düzce Üniversitesi Bilim ve Teknoloji Dergisi, 4, 104-112.
8. Kalın, V., 2005. Tekstil Atıkları ve Pamuk Linterinden Kağıt Hamuru ve Kağıt Üretim Koşullarının Belirlenmesi, Kahraman Maraş Sütçü İmam Üniversitesi Fen Bilimleri Enstitüsü Tekstil Mühendisliği Anabilimdalı Yüksek Lisans Tezi, 62.

9. Usta, İ., Akalın, M., Koçak, D., Merdan, N., Taşdemir, M., 2003. Farklı Oranlardaki Pamuk Atıkları (Telef) ile Desteklenmesi PP Polimerinin Oluşturduğu Kompozit Yapıların Mekanik ve Akış Özelliklerinin İncelenmesi, Gazi Üniversitesi Fen Bilimleri Dergisi 16(2), 403-410.

10. Prasad, S., Sigh, A, Joshi, H., 2007. Ethanol as an Alternative Fuel from Agricultural, Industrial and Urban Residues. Resource Convers Recycle, 50, 1-30.

11. Chena, M., Xiaaa, L., Xueb, P., 2007. Enzymatik Hydrolysis of Corncob and Ethanol Production from Cellulosic Hydrolysate. International Biodeterioration and Biodegradation 59, 85-89.

12. Tucker, M., Kyoung, H.K., Newman, M.M., Nguyen, Q.A., 2003. Effects of Temperature and Moisture on Dilute Acid Steam Explosion Pretreatment of Corn Stover and Cellulase Enzyme Digestibilty, Applied Biochemistry and Biotechnology, 105(1), ISSN:0273-2289.

13. Öhgren, K., Vehmaanpera, J., Siika-Aho, M., Galbe, M., Viikari, L., Zacchi, G., 2007. High Temperature Enzymatic Prehydrolysis Prior to Simultaneous Saccharification and Fermentation of Steam Pretreated Cornstover for Ethanol Production. Enzyme and Microbial Technology 40, 607-613.

14. Kaar, W.E., Holtzapple, M.T., 2000. Using Lime Pretreatment to Facilitate the Enzymic Hydrolysis of Cornstover, Biomass and Bioenergy 18, 189-199.

15. Kristensen, J.B., Börjesson J., Bruun, M.H., Tjerneld, F., Jørgensen, H., 2007. Use of Surface Active Additives in Enzymatic Hydrolysis of Wheat Straw Lignocellulose. Enzyme and Microbial Technology 40, 888-895.

16. Cao, W., Sun, C., Liu, R., Renzhan, Y., Xiaowu, W., 2012. Comparison of the Effects of Five Pretreatment Methods on Enchancing the Enzymatic Digestibility and Ethanol 
Production from Sweet Sorghum Bagasse. Bioresource Technology, 111, 215-221.

17. Oberoi, H.S., Vadlania, P.V., Brijwania, K. Bhargav, V.K., Patil, R.T., 2010.. Enchaced Ethanol Production Via Fermentation of Rice Straw with Hydrolysate-adapted Candidatropicalis ATCC 13803, Process Biochemistry, 45, 1299-1306.

18. Tye, Y.Y., Lee, K.T., Wan Abdullah, W.N., Leh, C.P., 2016. The World Availability of Non-wood Lignocellulosic Biomass for the Production of Cellulosic Ethanol and Potential Pretreatments for the Enhancement of Enzymatic Saccharification Renewable Energy Reviews 60, 155-172.

19. Xing-cai, L., Jian-guang, Y., Wu-gao Zhang, Zhen, H., 2004. Effect of Cetane Number Improver on Heat Release Rate and Emissions of High Speed Diesel Engine Fueled with Ethanol-diesel Blend Fuel. Fuel 83, 2013-2020.

20. Yüksel, F., Yüksel, B., 2004. The use of Ethanol-gasoline Blend as a Fuel in an SI Engine, Renewable Energy 29, 1181-1191.

21. http://www.yegm.gov.tr/yenilenebilir/biyoetan ol.aspx 14.2.2018.

22. https://docplayer.biz.tr/241461-Biyoetanolkullanim-zorunlulugunun-turk-ekonomisindeyaratacagi-etkiler-dr-f-figen-ar-pankobirlikdunya-enerji-konseyi-turk-milli-komitesi.html 14.2.2018.

23. Adıgüzel, A.O., 2013. Lignoselülozik Materyallerden Biyoetanol Üretimi için Kullanilan Ön-Muamele ve Hidroliz Yöntemleri SAÜ. Fen Bil. Der. 17(3), 381-397.

24. Shesler, R., 1994. Ethanol production in Hawaii Processes, Feedstocks, and Current Economic Feasibility of Fuel Grade Ethanol Production in Hawaii Prepared for State of Hawaii Department of Business, Economic Development \& Tourism Final Report July.

25. Johannesen, R., 2018. Energy Efficiency \& Environmental News: Alcohol Production from Biomass, Florida Energy Extension Service 14.2.2018.

26. Understanding Biomass as a Source of Sugars and Energy, http://permanent.access.gpo.gov/ websites/www.ott.doe.gov/biofuels/understandi ng_biomass.html 14.2.2018.
27. Wheals, A.E., Basso, L.C., Alves, D.M.G., Amorim, H.V., 1999. Fuel Ethanol After 25 Years, Renewable Fuels Association TIBTECH December (Vol 17).

28. Zabed, H., Sahu, J.N., Boyce, A.N., Fasruq, G., 2016. Fuel Ethanol Production from Lignocellulosic Biomass: An Overview on Feedstocks and Technological Approaches. Renewable an Sustainable Energy Reviews 66, 751-774.

29. Alhalabi, K., 2007. Suriye ve Türkiye'de Üretilen Pamuk Liflerinin Özelliklerinin ve Eğrilme Yeteneklerinin Karşılaştırılmalı İncelenmesi. Çukurova Üniversitesi Fen Bilimleri Enstitüsü Yüksek Lisans Tezi, Adana

30. Raja, P.B., Sethuraman, M.G., 2008. Inhibitive Effect of Black Pepper Extract on the Sulphuric Acid Corrosion of Mild Steel. Materials Letters, 62(17), 2977-2979.

31. Anonymous Sheet, 2010. Fuel Ethanol Application. CellicCTec and HTec2-Enzymes for Hydrolysis of Lignocellulosic Materials. Novozymes A/S, Luna-01668:01.

32. Yang, Y., Sharma-Shivappa, R.R., Burns, J.C., Cheng, J., 2009. Saccharification and Fermentation of Dilute-Acid-Pretreated FreezeDried Switchgrass. Energy\&Fuels, 23(11), 5626-5635.

33. Pickering, G.J., Heatherbll, D.A., Barnes, M.F., 1998. Optimising Glucose Conversion in the Production of Reduced Alcohol Wine Using Glucose Oxidase. Food Research International, 31, 685-692.

34. Cordier, H., Mendes, F., Vasconcelos, I., François, J.M., 2007. A Metabolic and Genomic Study of Engineered Saccharomyces cerevisiae Strains for High Glycerol Production. Metabolic Engineering, 9, 364-378. 